\title{
REVIEW \\ Shaul Magid \\ Hasidism Incarnate: Hasidism, Christianity, and the Construction of Modern Judaism
}

(Stanford: Stanford University Press, 2014), xiï + 288 pp.

Arthur Green, Hebrew College

My friend and mentor, the neo-Hasidic Rabbi Zalman Schachter-Shalomi, in searching for a creative and sympathetic Jewish way of understanding Christianity, often referred to Jesus as the rebbe from Nazareth. Schachter-Shalomi, in thinking of Christians as hasidim and devotees of a beloved wonder-working rabbi who sometimes went a bit too far (as do other hasidim) in singing his praises, was opening the door to a reconciliation between the two faiths. Inspired both by frequent interaction with Catholic monastic communities and an important Protestant teacher (Howard Thurman at Boston University), this onetime hasid of the Lubavitcher rebbe was committed to a deep ecumenism that pushed the borders between sacred languages and faith communities, viewing all of human religion as engaged in a quest for a single truth.

Of course this perception of Jesus as a charismatic rebbe could be shared by a liberal Jew or a Unitarian. God sent a new message at (what was to become) the turn of the era, one that insisted on love and forgiveness as the essence of His Torah. Jesus' original band of hasidim was deeply impressed, even transformed, by that message. But once Paul preached Jesus to the Gentiles, that little group of Galilean fishermen was quickly overwhelmed by Romans and others who fell in love with the messenger more than with the message, transforming him into a Hellenistic deity whose body was to be regularly ingested in a new mystery rite. 
In either case, the use of Hasidism, an eighteenth-century Jewish mystical revival movement that is still a powerful current within Judaism, as a Jewish doorway to understanding Christianity remains intriguing. Here Shaul Magid takes it up in a systematic way. The early modern Hasidic movement is characterized by intense devotion of disciples to a spiritual master, around whom a community is formed. Its theology is deeply immanentist, the presence of God being sought and joyously celebrated throughout Creation, rather than exclusively in the study and fulfillment of His law. Heartfelt worship and cultivation of the inner life are also characteristics of Hasidism's intense spirituality. This combination of immanence, inward quest, and devotion to the rebbe frequently led the Hasidic preachers (whose writings are preserved and studied) to rather strong statements about the presence of God within the soul of each devotee, but especially within that of the rebbe, who is seen as a living embodiment of God's presence in our midst.

Can this be called "incarnational" Judaism? In a technical sense, it can. The divine presence is embodied in the person of the rebbe. Everything he does, down to the way he ties his shoes, is to be seen as having sacramental meaning. Yes, the Platonic biases against the body still live on the Hasidic world, such that the rebbe is seen to have the least coarsely physical of all bodies while still having a body. But even if Hasidism is incarnational, surely such a designation is also a provocational act of scholarship. Everyone knows that incarnation is the central teaching of Christianity, and its use in a Jewish context is intended to make a statement.

Just what statement is Magid trying to make, therefore, in his Hasidism Incarnate? From a strictly scholarly point of view, he is trying to tell us that rigid theological categorizations are not adequate in defining the borders between traditions. For this goal, he does an admirable job in showing aspects of incarnational thinking that exist within Judaism. This has ancient roots, perhaps most forcefully expressed in the Midrashic comment on Psalm 90:1: "Moses was half man and half God," a passage Magid surprisingly does not invoke. The Enoch / 
Metatron and Merkavah traditions are filled with ascents to the heavens and descriptions of the elevated origins of humanity that are redolent of the doctrine of theosis in the surrounding Eastern Christian culture. In earthbound Hasidism, which Magid rightly notes was created in a cultural matrix distant from the "Christian gaze," this is often expressed in terms of divine descent into the person rather than human ascent to the heavens (p. 4). But it is most often every Jewish soul, or the souls of all the righteous, that contain the divine presence, rather than a single human incarnation. Yes, the rebbe is the channel of blessing to the community, surely an intercessor and even a divine / human intermediary, but is he truly a unique incarnation of God? One needs to push the point to find this, and Magid does indeed push. He does this best by invoking Rabbi Nahman of Bratslav, whose disciples thought of him as the only rebbe for the ages, and continued to revere him after his death. But Nahman is well-known as an outlier within Hasidic history.

Perhaps the most interesting part of Magid's very sophisticated argument is his final chapter, invoking the work of Elliot Wolfson. There he shows how in Judaism the person assimilates to the word of God through the medium of Torah, in which God has made Himself fully present. The Talmud already reads the opening word of the Decalogue anokhi, "I am," as an abbreviation meaning: "I Myself wrote and gave [the Torah]." This was probably first uttered in the context of ancient Jewish-Christian polemic. Some Hasidic sources read it with a different meaning: "I wrote and gave Myself", which is to say that God is verbally present in Torah. The Jew who engages in Torah thus fully partakes of the divine self.

But is it fair to call this incarnation? There is no carne here, after all, no flesh. One might coin a term like "inverbation" to characterize this Jewish idea, which is widely expressed. The human body, say the Kabbalists, has 613 limbs, parallel to Torah's 613 commandments. Abraham discovered the Torah, which is the divine presence, within himself. But he did so by looking beyond his bodily limbs into those of the spirit, seeing 
naught but the letters and words of Torah. So too the devotee, who is turning away from his own bodily self and entering the word. Is that incarnation?

I cannot but suspect, therefore, that Magid has a bigger goal in mind than just that of comparative theology. In his prior book he invoked Schachter-Shalomi (and me, to a lesser extent) as representing what he called "post-Judaism," a religious tendency that was ready to transcend all religious barriers in the name of a universal and borderless contemporary spiritual quest. (He also dedicates this book to Schachter-Shalomi.) Once monotheism shifts toward monism, he argued, the oneness of all being also demands the oneness of all faiths. This attempt to show that the lines between Judaism and Christianity are arbitrary and somewhat erasable appears to be part of Magid's larger project. While Schachter-Shalomi sometimes said things like that under the influence of Perrenialist and Integral thinking, I do not believe that was his ultimate intent. I believe it even less so when applied to the Ba'al Shem Tov.

That said, this is a challenging, always interesting, and learned book. Magid has read widely and brings together periods and figures who are seldom juxtaposed. I learned a great deal from it, both about Jewish perceptions of Christianity in the twentieth century and about ongoing scholarly disputes around the meaning of obscure and subtle Jewish mystical texts. 